\title{
ANALISA PENGARUH TOPOGRAFI DAN POLA TATA GUNA LAHAN TERHADAP ABSTRAKSI DAERAH ALIRAN SUNGAI BERDASARKAN MODEL RAINFALL RUNOFF
}

\author{
Ariani Budi Safarina
}

\begin{abstract}
ABSTRAK Penelitian ini bertujuan menganalisa pengaruh topografi dan tataguna lahan terhadap volume abstraksi pada suatu daerah aliran sungai. Pada penelitian ini dianalisa model rainfall runoff sepuluh daerah aliran sungai di Pulau Jawa dengan variasi karakteristik dan pola tata guna lahan. Model ini menganalisa mekanisme terjadinya limpasan karena suatu event hujan. Untuk mendapatkan jumlah limpasan, pada model ini dianalisa besarnya abstraksi dengan menggunakan metoda indeks phi, dimana laju abstraksi diasumsikan konstan. Berdasarkan hasil penelitian, diketahui bahwa terdapat hubungan logaritmis antara tataguna lahan dengan jumlah abstraksi. Pada musim kemarau, jumlah abstraksi 16\% lebih besar dari abstraksi pada musim penghujan. Untuk kemiringan DAS yang sama, abstraksi lebih besar jika jumlah hutan dan kebun yang lebih besar. Selain itu, abstraksi juga dipengaruhi oleh luas DAS dengan hubungan logaritmis, dimana abstraksi semakin besar dengan bertambahnya luas DAS tetapi pada luasan diatas $1000 \mathrm{~km}^{2}$, penambahannya lambat atau asympthotis. Debit puncak DAS tidak menunjukkan konsistensi terhadap tataguna lahan, dan mempunyai hubungan linier dengan luas DAS dengan gradient 0.022 pada koefisien determinasi $\mathrm{R}^{2}$ sebesar 0.772
\end{abstract}

Kata kunci: Abstraksi, Konvolusi, Model Rainfall Runoff

Naskah masuk : 26 Oktober 2011

Naskah diterima : 27 Maret 2012

Ariani Budi Safarina

Teknik Sipil Universitas Jenderal Achmad Yani

E-mail: arianibudis@yahoo.com
ABSTRACT This study aims to analyze the influence of topography and land use to the volume of abstraction in a watershed.In this study analyzed rainfall runoff model of ten watersheds in Java with variations in the characteristics and land use patterns. This model analyzes the mechanisms of runoff due to a rainfall event. In this model was analyzed abstraction used Phi Index method, where the rate of abstraction is assumed constant. The results of this study indicate there is a logarithmic relationship between land uses by the number of abstraction. In the dry season, the number of abstraction 16\% larger than the abstraction of the wet season. For the same watershed slope, abstraction is greater if the amount of forest and garden bigger. Moreover, the abstraction is also influenced by the watershed area with a logarithmic relationship, where the abstraction increase with the increase of watershed area but in an area of over $1,000 \mathrm{~km}^{2}$, the addition is slow or asympthotis. Peak discharge does not show the consistency of land use, and has a linear relationship with an area of watershed with gradient 0.022 and determination coefficient, $R^{2}$, is 0.772

Keyword: Abstraction, Convolution, Rainfall Runoff Model

\section{PENDAHULUAN}

Kerusakan daerah aliran sungai (DAS) dapat menimbulkan berbagai bencana yaitu banjir, kekeringan dan longsor. Salah satu faktor yang penting dalam kerusakan DAS adalah terjadinya lahan kritis yang setiap tahun makin meningkat (Siswoko, 2007 dari Safarina, 2010).

Penyebab kerusakan DAS adalah implementasi pengaturan tata ruang yang kurang memadai sehingga aktifitas pembangunan fisik terus mendesak wilayah resapan air. Implikasi dari hal ini yaitu pengurangan lahan tempat abstraksi air ke 
dalam tanah sehingga merusak fungsinya sebagai media penyimpan air. Akibatnya terjadi penurunan kelembaban dan kesuburan tanah sehingga lahan menjadi tidak produktif Yudha dkk (2005). Hundecha and Bardossy (2004), dalam penelitiannya memodelkan pengaruh perubahan land use pada limpasan, dengan mengaplikasikan model rainfall runoff terhadap 95 buah DAS di sungai Rhine, Jerman. Mereka menemukan bahwa debit rata rata meningkat hingga sepuluh kali jika urbanisasi dinaikkan dua kali, dan penghutanan kembali dapat menurunkan debit puncak. Khasanah dkk (2004), dalam penelitiannya menyatakan bahwa pada lahan miring, hujan akan mengalir di permukaan tanah sebagai limpasan permukaan, jumlah air yang tersedia untuk tanaman berkurang dan sebagian lapisan tanah atas akan hilang bersama-sama dengan limpasan permukaan (erosi). Sebuah model simulasi digunakan untuk mempelajari limpasan permukaan dan erosi akibat perubahan kualitas struktur tanah.

Curah hujan yang jatuh di permukaan DAS merupakan air atmosfir yang terdistribusi sebagai air di lahan, air permukaan di sungai dan infiltrasi ke dalam tanah Das (2002). Mekanisme ini secara natural terjadi seimbang dalam suatu siklus hidrologi. Jika lahan resapan air berkurang, maka sebagian besar air mengalir sebagai air permukaan yang berpotensi mengakibatkan banjir. Sebagai contoh, pada hidrograf aliran sungai Ciliwung, tercatat debit puncak di Katulampa terjadi hanya dua jam setelah terjadinya hujan Safarina (2010). Waktu puncak yang sangat singkat ini menunjukkan bahwa sebagian besar curah hujan yang jatuh di permukaan DAS Ciliwung mengalir sebagai air permukaan.

Penelitian ini bertujuan untuk menganalisa hubungan antara pola tataguna lahan dengan berbagai besaran hidrologis suatu DAS yaitu abstraksi, musim, waktu puncak, debit puncak dan dianalisa pula mekanisme runoff routing yang banyak dipengaruhi oleh kondisi topografi yaitu kemiringan lahan.

\section{Lokasi Penelitian}

Penelitian ini dilakukan di sepuluh daerah aliran sungai di Pulau Jawa, dengan posisi geografis setiap DAS ditunjukkan pada Tabel 1.

\section{METODOLOGI PENELITIAN}

Metodologi yang dilakukan dalam penelitian ini dapat diuraikan sebagai berikut:

- Peta hidrologi setiap DAS disusun berdasarkan peta rupa bumi $1: 25000$ yang dioverlapkan dan didigitasi ulang dengan dilengkapi koordinat stasiun curah hujan dan stasiun pengukur muka air (outlet). Alasan pemilihan peta digital adalah agar analisa yang berhubungan dengan posisi geografis seperti ketinggian, panjang sungai dll, dapat diperoleh dengan lebih teliti.

- Model rainfall runoff dalam bentuk hidrograf satuan ditentukan dengan metoda konvolusi dimana curah hujan diasumsikan sebagai input pulsa data diskrit yang responnya adalah debit sungai. Metoda ini dipilih karena dapat menganalisa dengan rinci pengaruh banyak curah hujan effektif dalam $n$ buah durasi yang dikonvolusikan dengan hydrograf satuan dan pengaruhnya terhadap debit di sungai.

- Metoda Phi Index untuk menentukan jumlah abstraksi dipilih karena metoda ini adalah metoda yang sederhana dan mudah diaplikasikan terutama jika data curah hujan real time diketahui, walaupun diasumsikan laju abstraksi konstan.

\section{Karakteristik Daerah Aliran Sungai}

Karakteristik fisik utama dari suatu DAS adalah luas, bentuk, elevasi, kemiringan, jenis tanah, jaringan saluran, kapasitas penampungan air dan tutupan lahan (Gupta,1989). Pengaruh jenis karakteristik tersebut berbeda-beda. Jenis tanah dapat mengontrol infiltrasi, tampungan air permukaan, dan air dalam tanah. Pengaruh yang dikombinasikan dari semua faktor adalah klasifikasi untuk DAS kecil dan DAS besar. Stefan Uhlenbrook, et.al (2004) dalam papernya mendefinisikan bahwa, sesuai luasnya, DAS dibagi menjadi DAS kecil $(\mathrm{A} \leq 1 \mathrm{~km} 2)$, DAS sedang (10 $\mathrm{km} 2<\mathrm{A} \leq 1000 \mathrm{~km} 2)$ dan DAS besar $(\mathrm{A}>1000$ $\mathrm{km} 2$ ). 
Tabel 1. Posisi Geografis DAS

\begin{tabular}{|c|c|c|c|c|}
\hline No & Nama DAS & Sungai Utama & Outlet & $\begin{array}{l}\text { Posisi Geografis } \\
\end{array}$ \\
\hline \multirow[t]{2}{*}{1} & Citarum-Nanjung & Citarum & Nanjung & $-6.75^{\circ} \mathrm{LS}$ sampai $-7.24^{\circ} \mathrm{LS}$ dan \\
\hline & & & & $107.37^{\circ} \mathrm{BT}$ sampai $107.94^{\circ} \mathrm{BT}$ \\
\hline \multirow[t]{2}{*}{2} & Cisangkuy-Kamasan & Cisangkuy & Kamasan & $-7.04^{0} \mathrm{LS}$ sampai $-7.23^{0} \mathrm{LS}$ dan \\
\hline & & & & $107.48^{0} \mathrm{BT}$ sampai $107.64^{0} \mathrm{BT}$ \\
\hline \multirow[t]{2}{*}{3} & Ciliwung-Sugutamu & Ciliwung & Sugutamu & $-6^{-34^{\circ}} \mathrm{LS}$ sampai $-6^{-76^{\circ} \mathrm{LS} \text { dan }}$ \\
\hline & & & & $106.79^{\circ} \mathrm{BT}$ sampai $107.00^{\circ} \mathrm{BT}$ \\
\hline \multirow[t]{2}{*}{4} & Cimanuk-Leuwidaun & Cimanuk & Leuwidaun & $-7.13^{0} \mathrm{LU}$ sampai $-7.4^{0} \mathrm{LU}$ dan \\
\hline & & & & $107.7^{0} \mathrm{BT}$ sampai $107.96^{\circ} \mathrm{BT}$ \\
\hline \multirow[t]{2}{*}{5} & Cikeruh-Jatiwangi & Cikeruh & Jatiwangi & $-6.72^{\circ} \mathrm{LU}$ sampai $-6.89^{\circ} \mathrm{LU}$ dan \\
\hline & & & & $108.27^{\circ} \mathrm{BT}$ sampai $108.40{ }^{\circ} \mathrm{BT}$ \\
\hline \multirow[t]{2}{*}{6} & Cilutung-Damkamun & Cilutung & Damkamun & $-6.75^{0} \mathrm{LU}$ sampai $-7.04^{0} \mathrm{LU}$ dan \\
\hline & & & & $108.11^{\circ} \mathrm{BT}$ sampai $108.40^{\circ} \mathrm{BT}$ \\
\hline \multirow[t]{2}{*}{7} & Serayu-Banyumas & Serayu & Banyumas & $-7.23^{0} \mathrm{LS}$ sampai $-7.69^{\circ} \mathrm{LS}$ dan \\
\hline & & & & $108.94^{\circ}$ BT sampai $109.30^{\circ} \mathrm{BT}$ \\
\hline \multirow[t]{2}{*}{8} & Klawing-Pegandekan & Klawing & Pegandekan & $-7.16^{0} \mathrm{LS}$ sampai $--7.69^{0} \mathrm{LS}$ dan \\
\hline & & & & $108.94{ }^{\circ} \mathrm{BT}$ sampai $109.83^{\circ} \mathrm{BT}$ \\
\hline \multirow[t]{2}{*}{9} & Progo-Duwet & Progo & Duwet & $-7.53^{\circ} \mathrm{LS}$ sampai $-7.69^{\circ} \mathrm{LS}$ dan \\
\hline & & & & $110.20^{\circ} \mathrm{BT}$ sampai $110.43{ }^{\circ} \mathrm{BT}$ \\
\hline \multirow[t]{2}{*}{10} & Amprong-Mahdyopuro & Amprong & Mahdyopuro & $-7.89^{0} \mathrm{LS}$ sampai $-8.05^{\circ} \mathrm{LS}$ dan \\
\hline & & & & $112.66^{\circ} \mathrm{BT}$ sampai $112.88^{\circ} \mathrm{BT}$ \\
\hline
\end{tabular}

Pada DAS kecil, respon curah hujan didominasi oleh proses generasi limpasan dari hulu dan wilayah dekat sungai. DAS sedang merupakan kombinasi DAS kecil yang terintegrasi secara terpadu dengan cara yang kompleks. Pada skala ini proses air di saluran (runoff routing, interaksi antara air tanah dan air permukaan) menunjukkan semakin penting dengan meningkatnya luas DAS. DAS besar menunjukkan distribusi curah hujan spasial dan temporal, dan runoff routing yang sangat dominan Uhlenbrook et.al, (2004).

\section{Aliran Permukaan}

Pengaliran air di permukaan DAS merupakan proses yang kompleks, karena bervariasi dalam tiga dimensi ruang dan waktu. Dimulai ketika air tergenang di permukaan DAS, pada kedalaman yang cukup menghasilkan gaya retensi permukaan dan mulailah terjadi aliran.

Air Permukaan adalah air yang tersimpan atau mengalir di permukaan bumi. Sistem air permukaan terdiri dari proses aliran di lahan (overland flow), limpasan permukaan (surface runoff), outflow dari aliran bawah permukaan (subsurface) dan air tanah (groundwater) dan limpasan (runoff) ke sungai dan laut. Chow and larry (1988).
Dua jenis aliran dapat dibedakan secara mendasar yaitu aliran di lahan (overland flow) dan aliran di saluran (channel flow). Aliran lahan mempunyai lapisan tipis dengan permukaan yang luas, sedangkan aliran saluran merupakan aliran di dalam saluran yang lebih sempit dan dalam lintasan yang terbatas. Pada DAS yang natural, aliran lahan merupakan awal mekanisme pengaliran air permukaan namun hanya dapat bertahan pada jarak yang pendek (sampai dengan $100 \mathrm{ft}$ ) sebelum ketidak seragaman permukaan DAS memusatkan aliran pada saluran yang berliku-liku. Secara bertahap, dari saluran sungai sungai kecil ini bergabung ke saluran-saluran yang terakumulasi ke arah hilir dan membentuk aliran di outlet DAS.

Aliran air permukaan mengikuti prinsip-prinsip kontinuitas dan momentum. Aplikasi prinsip prinsip tersebut untuk aliran unsteady tiga dimensi pada permukaan DAS memungkinkan hanya untuk kondisi yang sangat disederhanakan, sehingga asumsi yang digunakan adalah satu atau dua dimensi Chow Ven Te et.al, (1988).

Aliran pada dataran seragam dimana hujan jatuh memiliki intensitas i dan laju infiltrasi yang terjadi adalah f. Dalam waktu ini seluruh aliran dalam kondisi stabil. Ukuran dataran adalah dalam satuan 
lebar dan panjang $\mathrm{L}_{\mathrm{o}}$, dengan sudut kemiringan terhadap horisontal, $\Theta$, sehingga slope $S_{0}=\tan \Theta$

Persamaan kontinuitas untuk aliran stabil dengan $\rho$ konstan adalah

$$
\iint_{c s} V \cdot d A=0
$$

Aliran yang masuk ruang tilik (control volume) dari hujan adalah $\mathrm{iL}_{0} \cos \Theta$, dan yang keluar adalah $\mathrm{f}_{\mathrm{o}} \cos \Theta$ dari infiltrasi ditambah $\mathrm{V}_{\mathrm{y}}$ dari aliran lahan. Kedalaman y diukur tegak lurus terhadap dasar dan kecepatan V sejajar dasar. Persamaan kontinuitas menjadi:

$$
\iint_{c s} V \cdot d A=f L o \cos \theta+V y-i L o \cos \theta=0
$$

Debit per satuan lebar, qo adalah:

$\mathrm{qo}=\mathrm{Vy}=(\mathrm{i}-\mathrm{f}) \mathrm{Lo} \cos \Theta$

Aliran laminer yang seragam pada dataran yang miring memiliki kecepatan rata-rata $\mathrm{v}$ :

$$
V=\frac{g S_{o} y^{2}}{3 v}
$$

dimana g adalah percepatan gravitasi dan $v$ adalah viskositas kinematik aliran. Untuk aliran seragam, So $=\mathrm{Sf}=\mathrm{h}_{\mathrm{f}} / \mathrm{L}$, sehingga persamaan (4) menjadi

$$
h_{f}=\frac{24 v}{V_{y}} \frac{L}{4 y} \frac{V^{2}}{2 g}
$$

dimana dalam bentuk persamaan Darcy-Weisbach untuk aliran dengan hambatan

$$
h_{f}=f \frac{L}{4 R} \frac{V^{2}}{2 g}
$$

dengan faktor gesekan $\mathrm{f}=96 / \mathrm{Re}$ dimana bilangan Reynold $\mathrm{Re}$ adalah $\mathrm{Re}=4 \mathrm{VR} / \mathrm{v}$, dan jari-jari hidraulik R = y Roberson dan Crowe, (1985), dari Chow et.al, (1988). Untuk aliran dengan satuan lebar sheet, $\mathrm{R}=$ luas/keliling basah $=\mathrm{yxl} / 1=\mathrm{y}$. Aliran laminer bilangan Reynoldnya $\operatorname{Re} \leq 2000$.

Untuk aliran sheet laminer akibat hujan, faktor gesekan bertambah sesuai intensitas hujan. Diasumsikan bahwa $f=C_{L} / \operatorname{Re}$ dimana $C_{L}$ adalah koefisien hambatan, yang berdasarkan penelitian di University of Illinois, Chow dan Yen (1976) dari Chow, et.al (1988) memberikan
$\mathrm{C}_{\mathrm{L}}=96+108 \mathrm{i}^{0.4}$

dimana i adalah intensitas hujan dalam inch/jam.

Penyelesaian untuk y dari persamaan (5) dan menggunakan $\mathrm{So}=\mathrm{h}_{\mathrm{f}} / \mathrm{L}$ untuk aliran seragam, didapatkan

$y=\frac{f V^{2}}{8 g S_{o}}$

Dengan mensubtitusikan qo $=\mathrm{Vy}$, maka

$y=\left(\frac{f q_{o}^{2}}{8 g S_{o}}\right)^{1 / 3}$

Persamaan di atas adalah untuk kedalaman aliran sheet pada dataran seragam.

\section{Abstraksi}

Abstraksi meliputi intersepsi curah hujan pada tanaman atau bangunan di atas tanah, tampungan depresi sebagai akumulasi air pada cekungan tanah lembah di atas permukaan, dan infiltrasi air dalam tanah (Gray,1961). Abstraksi penyimpanan intersepsi dan depresi diestimasi berdasarkan kondisi penutupan lahan dan permukaan tanah atau diasumsikan diabaikan dalam badai besar.

Dalam kebanyakan masalah hidrologi, hidrograf aliran tidak tersedia dan abstraksi harus ditentukan dengan menghitung infiltrasi dan menghitung secara terpisah bentuk abstraksi lain, seperti misalnya intersepsi, dan tampungan detensi atau depresi. Dalam penentuan abstraksi menggunakan metode infiltrasi ini, diasumsikan bahwa semua abstraksi timbul dari infiltrasi. Overland flow adalah aliran permukaan yang sangat tipis yang terjadi di atas lahan sebelah udik saluran sebelum air terkonsentrasi ke saluran atau sungai Chow Ven Te et.al, (1988). Hujan efektif adalah curah hujan yang turun tidak termasuk yang tertahan di lahan dan yang terinfiltrasi di tanah. Setelah mengalir melalui permukaan DAS, hujan efektif menjadi limpasan langsung pada outlet DAS dengan asumsi aliran overland dari horton. Grafik antara hujan efektif dan waktu atau hyetograf hujan efektif (ERH) merupakan komponen kunci dari studi tentang hubungan rainfall-runoff. Perbedaan antara hyetograph curah hujan total pada pengukuran observasi dengan hyetograph curah hujan efektif adalah abstraksi atau losses. Losses terutama karena infiltrasi, intersepsi dan tampungan air permukaan. 
Hyetograph hujan efektif dapat ditentukan jika tersedia data aliran untuk suatu kejadian hujan. Pemisahan aliran dasar dilakukan untuk menghasilkan hidrograf limpasan langsung. Untuk menentukan hujan efektif, parameter dari persamaan infiltrasi dapat ditentukan dengan metoda $\varnothing$ indeks. $\varnothing$ indeks adalah laju konstan dari abstraksi (in/jam atau $\mathrm{cm} / \mathrm{jam}$ ) yang akan menghasilkan hyetograf hujan efektif (ERH) dengan total kedalaman sama dengan kedalaman limpasan langsung rd. Nilai $\varnothing$ ditentukan dengan memilih lama interval waktu $\Delta \mathrm{t}$, dengan menetapkan jumlah interval $M$ yang mengkontribusi limpasan langsung, mengurangkan $\varnothing \Delta \mathrm{t}$ dari pengukuran curah hujan setiap interval, dan mencari nilai $\varnothing$ sesuai persamaan :

$$
r_{d}=\sum_{m=1}^{M}\left(R_{m}-\phi \Delta t\right)
$$

\section{Model Rainfall Runoff}

Model rainfall runoff ditentukan dengan analisa hidrograf. Hidrograf satuan adalah unit pulsa yang merupakan fungsi respon dari sistem hidrologi linier, dan pertama kali dikeluarkan oleh Sherman (1938) dari Chow Ven Te et.al (1988). Hidrograf satuan dari sebuah DAS didefinisikan sebagai hidrograf limpasan langsung yang dihasilkan dari satu inch atau satu $\mathrm{cm}$ hujan efektif yang diturunkan secara seragam di setiap titik dalam DAS, pada kecepatan konstan dan durasi efektif. Hidrograf satuan adalah model linier sederhana yang dapat digunakan untuk mendapatkan hydrograf yang dapat ditentukan dari setiap hujan efektif. Asumsi dasar yang digunakan dalam model linier ini adalah:

1. Hujan efektif mempunyai intensitas yang konstan selama durasi efektif.

2. Hujan efektif didistribusikan secara seragam di setiap titik dalam DAS.

3. Basis waktu hidrograf limpasan langsung dari suatu hujan efektif dengan durasi tertentu adalah konstan.

4. Ordinat hidrograf limpasan langsung dari sebuah aliran dasar sebanding dengan jumlah total hujan efektif untuk setiap hidrograf.
5. Untuk suatu DAS, hidrograf yang dihasilkan bagi setiap hujan efektif tertentu menggambarkan karakteristik DAS yang sama.

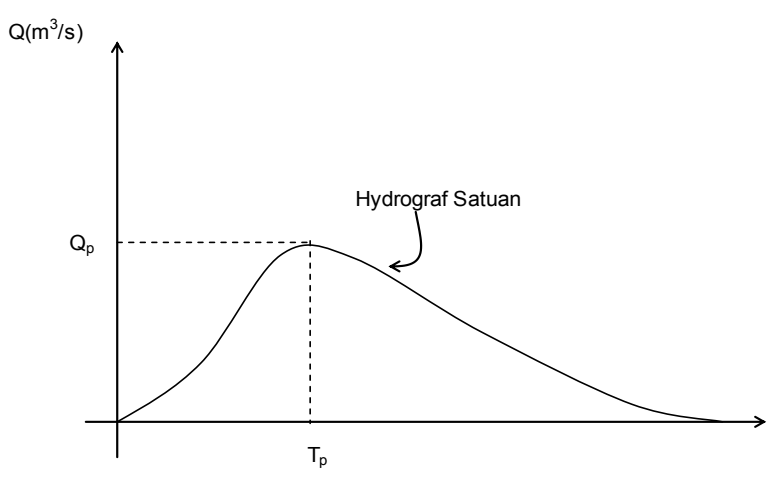

Gambar 1. Unit Hidrograf

Gambar 1 menunjukkan bentuk umum dari hidrograf satuan suatu DAS. Hidrograf satuan ini menunjukkan run off untuk setiap luas DAS dan setiap $1 \mathrm{~mm}$ hujan efektif.

\section{Metoda Konvolusi}

Respon dari sistem linier dikarakterisasikan secara unik dengan fungsi respon impuls. Suatu impuls, baik fungsi step maupun fungsi respon pulsa, didefinisikan mempunyai domain waktu kontinu. Jika domain waktu didiskritisasi dengan interval durasi $\Delta \mathrm{t}$, maka terdapat dua cara untuk menggambarkan fungsi waktu kontinu dalam domain waktu diskrit, yaitu sistem data pulsa dan sistem data sampel. Sistem data pulsa digunakan untuk presipitasi dan nilai dari fungsi input diskrit adalah:

$$
P m=\int_{(m-1) \Delta t}^{m \Delta t} I(\tau) d t \quad \mathrm{~m}=1,2,3 \ldots
$$

Pm adalah kedalaman presipitasi selama interval waktu (dalam milimeter). Sistem data sampel digunakan untuk aliran dan limpasan langsung, sehingga nilai dari output sistem pada waktu interval ke $\mathrm{n}(\mathrm{t}=\mathrm{n} \Delta \mathrm{t})$ adalah

$$
\mathrm{Qn}=\mathrm{Q}(\mathrm{n} \Delta \mathrm{t}) \quad \mathrm{n}=1,2,3, \ldots
$$


Tabel 2. Karakteristik DAS Lokasi Studi

\begin{tabular}{clcccc}
\hline No & \multicolumn{1}{c}{ Nama DAS } & Luas $\left(\mathbf{K m}^{\mathbf{2}}\right)$ & $\begin{array}{c}\text { Slope } \\
\mathbf{( \% )}\end{array}$ & $\mathbf{L}(\mathbf{K m})$ & Keterangan \\
\hline 1 & Citarum-Nanjung & 1762,59 & 0,61100 & 82,00 & DAS Besar \\
\hline 2 & Cisangkuy-Kamasan & 203,38 & 4,85000 & 34,00 & DAS Sedang \\
\hline 3 & Ciliwung-Sugutamu & 254,00 & 3,65000 & 78,00 & DAS Sedang \\
\hline 4 & Cimanuk-Leuwidaun & 450,68 & 0,03000 & 42,00 & DAS Sedang \\
\hline 5 & Cikeruh-Jatiwangi & 115,76 & 0,06000 & 30,00 & DAS Sedang \\
\hline 6 & Cilutung-Damkamun & 628,86 & 0,29500 & 55,17 & DAS Sedang \\
\hline 7 & Serayu-Banyumas & 2666,00 & 0,01500 & 140,19 & DAS Besar \\
\hline 8 & Klawing-Pegandegan & 1099,00 & 0,60000 & 42,59 & DAS Besar \\
\hline 9 & Progo-Duwet & 162,00 & 0,70000 & 33,27 & DAS Sedang \\
\hline 10 & Amprong-Mahdyopuro & 236,00 & 4,00000 & 34,00 & DAS Sedang \\
\hline
\end{tabular}

Qn adalah nilai sesaat dari aliran pada akhir interval waktu ke $\mathrm{n}$ (dalam $\mathrm{m}^{3} / \mathrm{s}$ ). Dengan demikian variabel input dan output untuk sistem DAS dicatat dengan dimensi yang berbeda dan menggunakan representasi data diskrit yang berbeda pula. Pengaruh atas pulsa input dari durasi $\Delta \mathrm{t}$ dimulai pada waktu $(\mathrm{m}-1) \Delta \mathrm{t}$ dan output pada waktu $\mathrm{t}=\mathrm{n} \Delta \mathrm{t}$ diukur dengan nilai fungsi respon unit pulsa $\mathrm{h}[\mathrm{t}-(\mathrm{m}-1) \Delta \mathrm{t}]=\mathrm{h}[\mathrm{n} \Delta \mathrm{t}-(\mathrm{m}-1) \Delta \mathrm{t}]=\mathrm{h}[(\mathrm{n}-\mathrm{m}+1) \Delta \mathrm{t}]$, maka persamaan 2 menjadi

$$
h[(n-m+1) \Delta t]=\frac{1}{\Delta t} \int_{(n-m) \Delta t}^{(n-m+1) \Delta t} u(l) d l
$$

Dengan mendiskritkan integral konvolusi pada $\mathrm{t}=\mathrm{n} \Delta \mathrm{t}$ dan mensubtitusikannya ke persamaan 13 , maka didapat persamaan konvolusi dengan input Pm dalam pulsa dan output Qn sebagai fungsi data sampel dari waktu :

$$
\begin{aligned}
\mathrm{Qn}=\mathrm{P}_{1} \mathrm{~h}[(\mathrm{n} \Delta \mathrm{t})] & +\mathrm{P}_{2} \mathrm{~h}[(\mathrm{n}-1) \Delta \mathrm{t}]+\ldots \\
& +\mathrm{P}_{\mathrm{m}} \mathrm{h}[(\mathrm{n}-\mathrm{m}+1) \Delta \mathrm{t}]+\ldots \\
& +\mathrm{P}_{\mathrm{M}} \mathrm{h}[(\mathrm{n}-\mathrm{M}+1) \Delta \mathrm{t}]
\end{aligned}
$$

Fungsi respon pulsa kontinu $h(t)$ dapat direpresentasikan kedalam domain waktu diskrit

sebagai fungsi data sampel U. Dengan demikian didapatkan persamaan konvolusi diskrit untuk sistem linier:

$$
Q n=\sum_{m=1}^{n \leq m} P_{m} U_{n-m+1}
$$

\section{HASIL PENELITIAN}

\section{Karakteristik DAS}

Pada penelitian ini dianalisa sepuluh DAS di pulau Jawa dengan berbagai karakteristik seperti ditunjukkan pada Tabel 2. Terdapat tiga karakteristik DAS yang dianalisa yaitu luas, panjang sungai utama dan slope. Slope merupakan kemiringan sungai utama yang disumsikan representatif terhadap kemiringan DAS rata rata.

DAS lokasi studi merupakan luas DAS dengan klasifikasi meso dan makro menurut klasifikasi Hundecha and Andras (2004).

\section{Tata Guna Lahan Lokasi Studi}

Prosentase hutan, dan kebun pada tata guna lahan dipilih karena representatif terhadap jumlah air yang terabstraksi

Tabel 3. Tata Guna Lahan DAS Lokasi Studi

\begin{tabular}{ccc}
\hline No & Nama DAS & $\begin{array}{c}\text { Hutan dan } \\
\text { Kebun } \\
\mathbf{( \% )}\end{array}$ \\
\hline 1 & Citarum-Nanjung & 50,90 \\
\hline 2 & Cisangkuy-Kamasan & 75,50 \\
\hline 3 & Ciliwung-Sugutamu & 43,03 \\
\hline 4 & Cimanuk-Leuwidaun & 80,00 \\
\hline 5 & Cikeruh-Jatiwangi & 69,70 \\
\hline 6 & Cilutung-Damkamun & 70,80 \\
\hline
\end{tabular}


Tabel 4. Besaran Hydrologis DAS Lokasi Penelitian

\begin{tabular}{ccccc}
\hline No & Nama DAS & $\begin{array}{c}\text { Debit Puncak } \\
\mathbf{Q p}\left(\mathbf{m}^{\mathbf{3}} / \mathbf{s}\right)\end{array}$ & $\begin{array}{c}\text { Waktu Puncak } \\
\mathbf{T p}(\mathbf{j a m})\end{array}$ & $\begin{array}{c}\text { Waktu Dasar } \\
\mathbf{T b}(\mathbf{J a m})\end{array}$ \\
\hline 1 & Citarum-Nanjung & 47,11 & 7 & 17 \\
\hline 2 & Cisangkuy-Kamasan & 5,50 & 5 & 22 \\
\hline 3 & Ciliwung-Sugutamu & 9,92 & 5 & 21 \\
\hline 4 & Cimanuk-Leuwidaun & 19,94 & 3 & 20 \\
\hline 5 & Cikeruh-Jatiwangi & 5,29 & 5 & 21 \\
\hline 6 & Cilutung-Damkamun & 14,11 & 5 & 30 \\
\hline
\end{tabular}

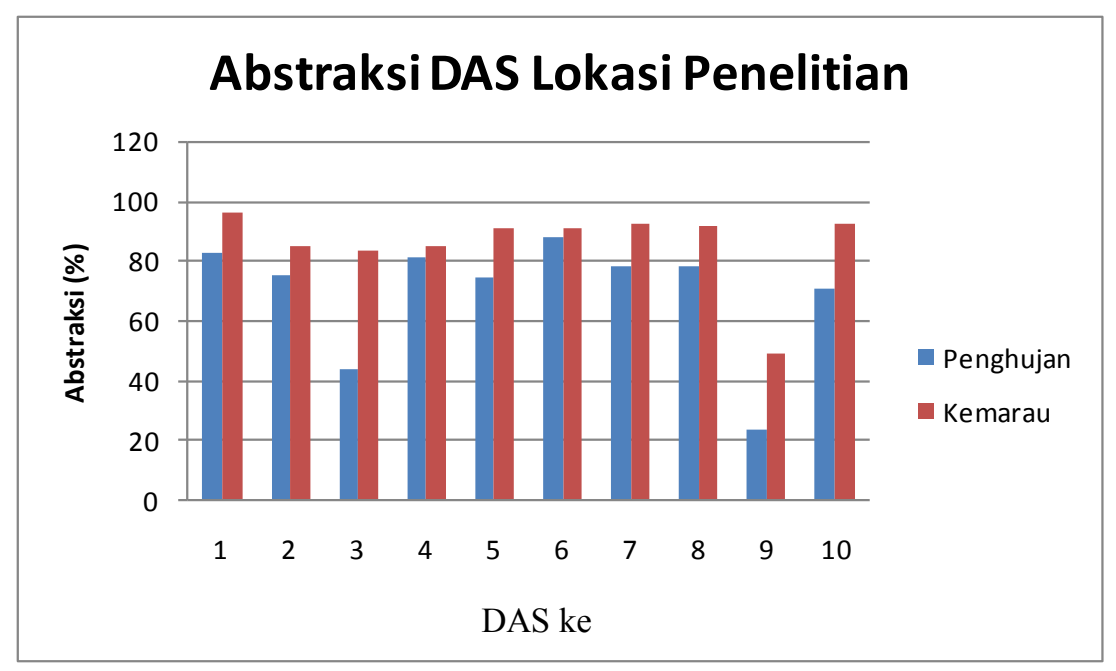

Gambar 2. Abstraksi DAS Lokasi Penelitian

Besaran hidrologis DAS dari model rainfall runoff yaitu debit puncak, waktu puncak dan waktu dasar untuk setiap DAS ditunjukkan pada Tabel 4.Debit puncak menunjukkan debit maksimum yang terjadi di outlet DAS untuk setiap event hujan, sedangkan waktu puncak adalah waktu yang dibutuhkan sejak pertama kali hujan hingga terjadi debit puncak, dan waktu dasar adalah waktu yang dibutuhkan hingga debit di outlet kembali seperti sebelum hujan,

\section{Abstraksi DAS Lokasi Studi}

Jumlah abstraksi tiap DAS untuk suatu event hujan, ditentukan dengan metoda $\varnothing$ Indeks dari model rainfall runoff, yaitu hidrograf, dimana diasumsikan laju abstraksi konstan dan limpasan terjadi merata di dalam DAS .

Kejadian hujan yang digunakan adalah kejadian hujan musim kemarau dan musim penghujan. Dari hasil penelitian didapat bahwa abstraksi pada musim kemarau sedikit lebih besar dari musim penghujan. Hal ini disebabkan kondisi tanah lebih kering pada musim kemarau.

\section{Pengaruh Tata Guna Lahan terhadap Abstraksi}

Pengaruh tata guna lahan terhadap abstraksi pada setiap DAS ditentukan dengan membuat grafik hubungan antara keduanya (Gambar 3). Persamaan hubungan antara tata guna lahan ( $\%$ hutan dan kebun) dan abstraksi musim penghujan dan musim kemarau ditentukan dengan persamaan regressi non linear fungsi logaritmis.

Hasil regresi untuk musim penghujan $\left(\mathrm{R}^{2}=0.802\right)$ :

$Y=35.31 \ln (x)-71.63$

Dan untuk musim kemarau $\left(\mathrm{R}^{2}=0.72\right)$ :

$\mathrm{Y}=22.47 \ln (\mathrm{x})-4.22$ 


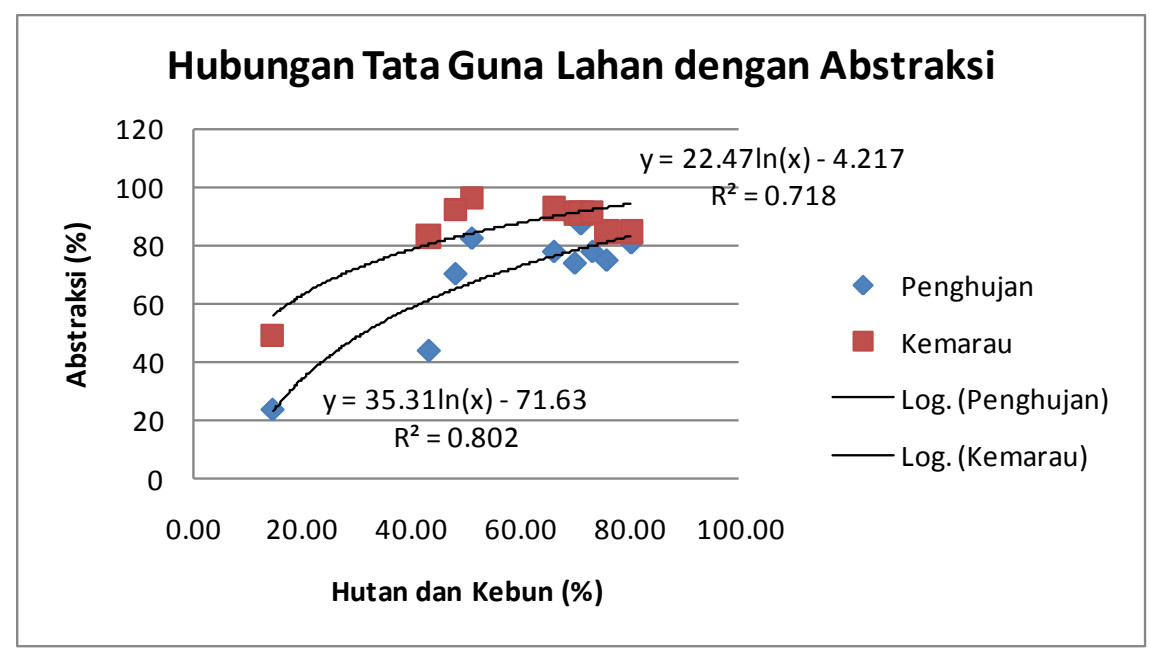

Gambar 3. Hubungan Tata Guna Lahan dan Abstraksi

Fungsi logaritmis menunjukkan bahwa abstraksi bertambah secara lambat dengan bertambahnya prosentase hutan dan kebun pada tata guna lahan. Jika dilakukan interpolasi untuk interval 10\% prosentase hutan dan kebun berdasarkan persamaan regressi yang dihasilkan, maka jika direncanakan prosentase hutan dan kebun 40\% untuk suatu DAS, maka abstraksi pada musim hujan sebesar $60 \%$ dan pada musim kemarau $78 \%$. Kurva hasil interpolasi ditunjukkan pada Gambar 4.

\section{Pengaruh Topografi Terhadap Abstraksi}

Parameter topografi yang digunakan dalam penelitian ini adalah kemiringan DAS. Berdasarkan kemiringan DAS dari sepuluh DAS lokasi penelitian, ditentukan grafik terhadap prosentase abstraksi. Dari grafik hubungan abstraksi dengan slope (gambar 5), ditunjukkan bahwa untuk rata rata slope, besar abstraksi rata rata sebesar $80 \%$, kecuali untuk DAS Progo-Duwet yaitu sebesar $23 \%$ dan DAS Ciliwung-Sugutamu sebesar 43\%. Pada DAS Progo-Duwet, penyebabnya karena DAS tersebut walau slope nya lebih kecil dari satu namun mempunyai prosentase hutan dan kebun hanya $14.5 \%$, sehingga limpasan lebih dominan daripada abstraksi. Untuk DAS Ciliwung-Sugutamu, walaupun prosentase hutan dan kebun lebih besar yaitu $43 \%$, tetapi slopenya $3,65 \%$, sehingga curah hujan yang jatuh lebih banyak mengalir sebagai limpasan .

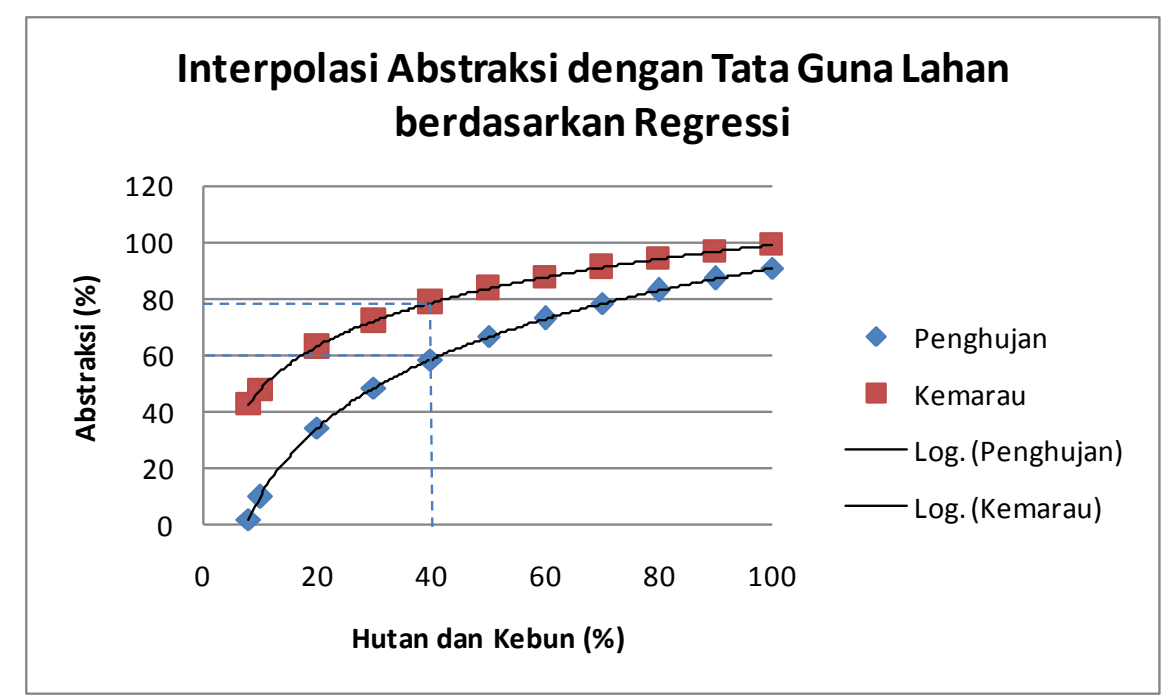

Gambar 4. Interpolasi Abstraksi Berdasarkan hasil Regressi 


\section{Pengaruh Tata Guna lahan Terhadap Besaran Hidrologis DAS}

Berdasarkan data pada penelitian ini, besaran hydrologis DAS tidak menunjukkan konsistensi terhadap prosentase hutan dan kebun (Gambar 6). Konsistensi ditunjukkan pada hubungan linier antara debit puncak dan luas DAS, dimana semakin besar luas DAS, maka debit puncak semakin tinggi. Hubungan ini sesuai dengan beberapa penelitian mengenai pengaruh parameter hidrograf terhadap karakteristik DAS Safarina (2010).
Berdasarkan Gambar 7 dapat ditentukan bahwa debit puncak linier terhadap luas DAS dengan gradien 0.022 dan koefisien determinasi 0.772 , sehingga korelasi dianggap cukup baik.

Berdasarkan Gambar 8, abstraksi dipengaruhi oleh luas DAS dengan hubungan logaritmis, dimana abstraksi semakin besar dengan bertambahnya luas DAS tetapi pada luasan diatas $1000 \mathrm{~km}^{2}$, penambahannya lambat mendekati $90 \%$ di tak hingga (asympthotis).

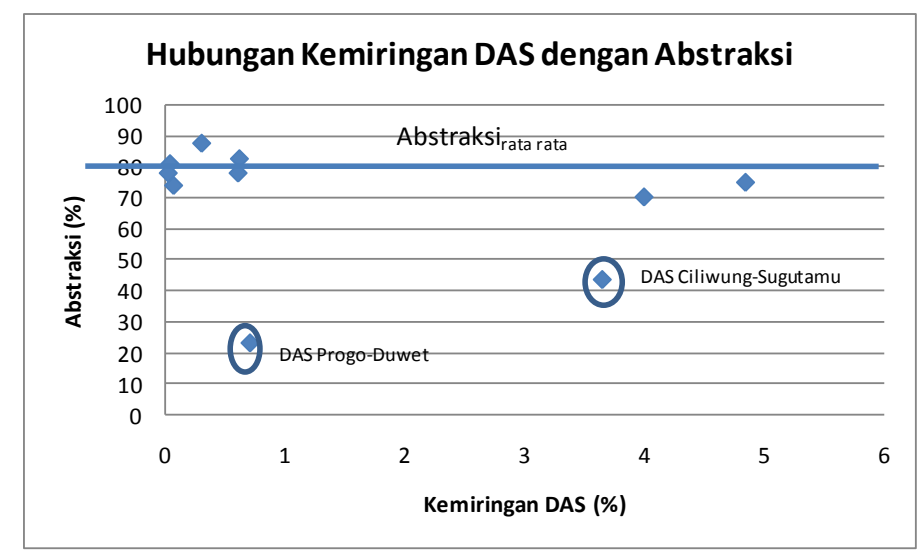

Gambar 5. Pengaruh Kemiringan DAS pada Abstraksi

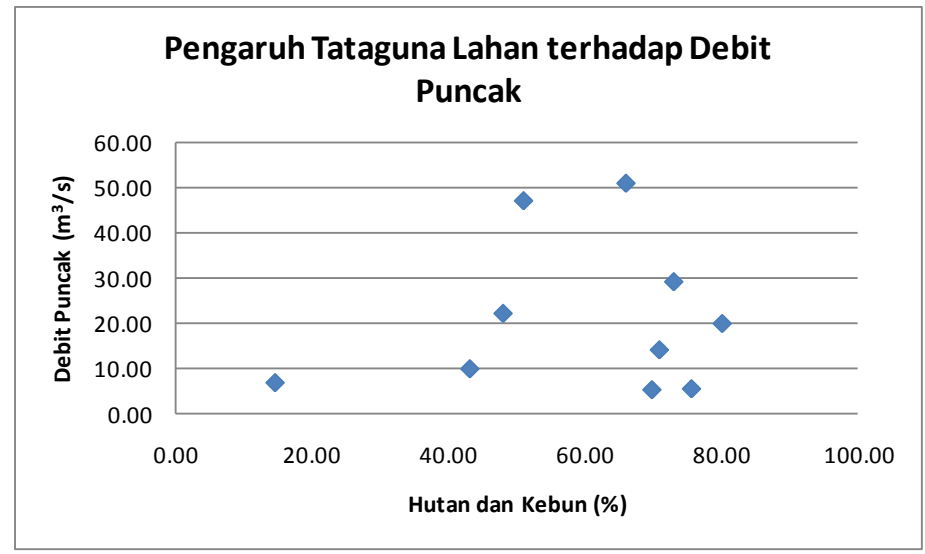

Gambar 6. Pengaruh Tataguna Lahan terhadap Debit Puncak

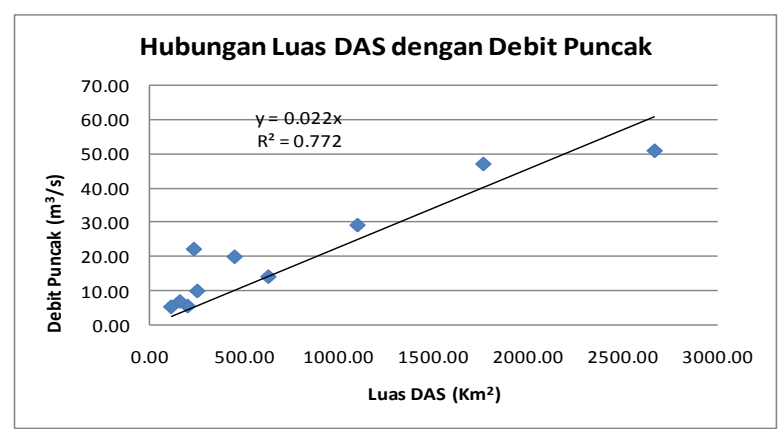

Gambar 7. Hubungan Luas DAS dengan Debit Puncak 


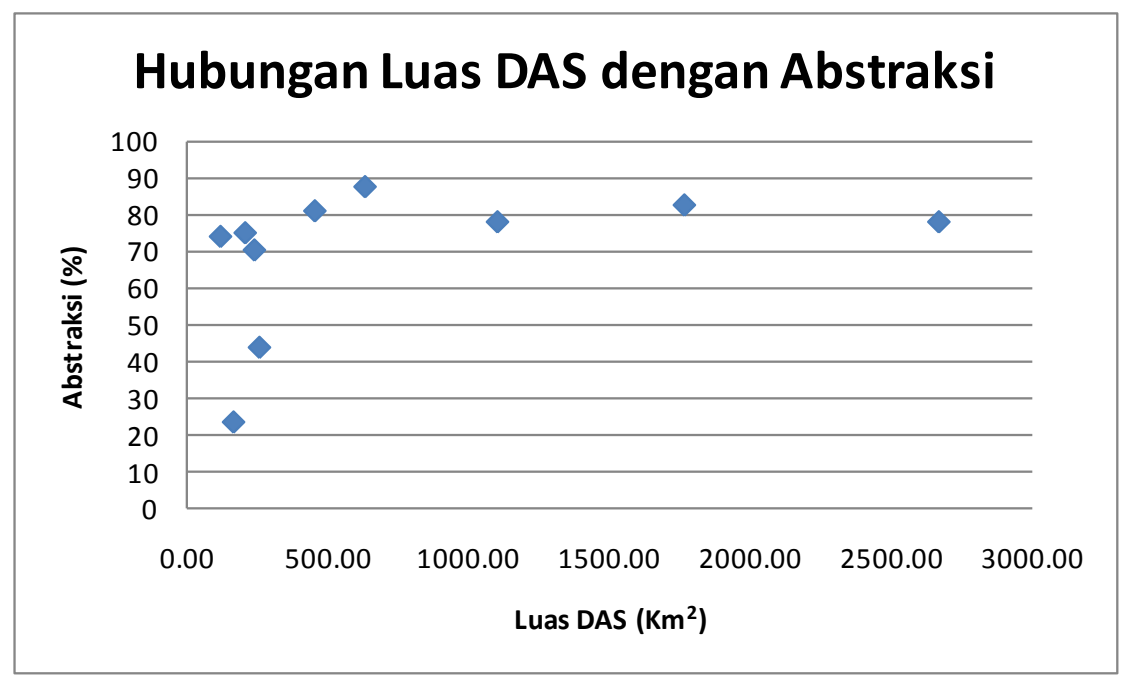

Gambar 8. Hubungan Luas DAS dengan Abstraksi

\section{KESIMPULAN}

Abstraksi pada suatu DAS dipengaruhi oleh jumlah hutan dan kebun dengan hubungan logaritmis dan pada musim kemarau jumlah abstraksi $16 \%$ lebih besar dari abstraksi pada musim penghujan. Untuk kemiringan DAS yang sama, abstraksi lebih besar jika jumlah hutan dan kebun lebih besar. Selain itu, abstraksi juga dipengaruhi oleh luas DAS dengan hubungan logaritmis, dimana abstraksi semakin besar dengan bertambahnya luas DAS tetapi pada luasan di atas $1000 \mathrm{~km}^{2}$, penambahannya lambat atau asympthotis. Debit puncak suatu DAS tidak menunjukkan konsistensi terhadap jumlah hutan dan kebun tetapi menunjukkan hubungan linier dengan luas DAS dimana semakin besar DAS maka debit puncak semakin besar dengan gradien 0.022 dan koefisien determinasi 0.772 .

\section{Daftar Pustaka}

Chow Ven Te, Maidment, Mays Larry W.,1988, Applied Hidrologi, McGraw-Hill International Edition

Das Ghanshyam, 2002, Hydrology and Soil Conservation Engineering, Prentice-Hall of India, New Delhi

Gupta Ram S, 1989, Hydrology and Hydraulic System, Prentice Hall New Jersey

Gray, D.M., 1961, Interrelationships of watershed characteristics, J. Geophys. Res.66.
Hundecha Y. and Andras B.(2004) : Modeling of the Effect of Land Use Changes on The Runoff Generation of a River Basin Trough Parameter Regionalization of a Watershed Model, Journal of Hydrology, Institut of Hydraulic Engineering, University of Stuttgart, Germany

Khasanah, N., Betha L., Farida dan Meine V.N. (2004) : Simulasi Limpasan Permukaan dan Kehilangan Tanah Pada Berbagai Umur Kebun Kopi: Studi Kasus di Sumberjaya, Lampung Barat, Agrivita vol.26 No.1, World Agroforestry Centre, ICRAF SE Asia, Bogor

Safarina A B, 2010, Model Analisa Metoda Hydrograf Satuan Sintetik Untuk Berbagai Karakteristik Daerah Aliran Sungai, disertasi, Institut Teknologi Bandung, Bandung

Uhlenbrook Stefan, Stefan Roser, Nils Tilch. (2003): Hydrological Process Representation at the Meso-scale:the Potential of a Distributed, Conceptual Catchment Model, Journal of Hydrology, Institut of Hydraulic Engineering, University of Stuttgart, Germany

Prawira Angga Yudha, Ketut Wikantika, Firman Hadi, 2005, 'Analisis Spasial Lahan Kritis di Kota Bandung Utara Menggunakan Open Source Grass, Proceeding, pertemuan ilmiah Tahunan MAPIN XIV, Surabaya 